\title{
STUDY OF BUTTERFLY SPECIES AT KONDANG MERAK BEACH SOUTHERN MALANG AREA
}

\author{
Herlina Putri Endah Sari, Sofia Ery Rahayu, Masjhudi, Fury Fauziah \\ Department of Biology, Faculty of Mathematics and Natural Science \\ State University of Malang, Jl. Semarang 5, Malang, Indonesia \\ E-mail: endahsarihp@gmail.com
}

\begin{abstract}
There are many variants of butterfly species living at Kondang Merak beach Southern Malang, Indonesia, but the information about their diversity has notbeen available yet. This research aimed to determine the diversity of butterfly species at Kondang Merak beach. This research was conducted in April 2013. The butterfly was captured using insect nett with standart walk method. This research found the total of 40 butterflies species belong to 5 families, i.e. Pieridae (15 species), Nymphalidae (14 species), Papilionidae (5 spesies), Lycaenidae (5 spesies) and Hesperidae (1 species). Ideopsis juventa from family of Nymphalidae is the most abundant species in this area. Further research is necessary in order to provide more complete database about the diversity of butterfly at Kondang Merak beach.
\end{abstract}

Keywords: Butterfly, Lepidoptera, Kondang Merak beach

\section{INTRODUCTION}

Kondang Merak is one of beautiful beach at Southern Malang area. Many variants of butterfly live around the macadam road and on the banks of Kondang Merak Beach. However, the information about database of butterfly spesies in Kondang Merak beach has not been availlable yet. Around the world, Butterfly is divided into 6 families, which are Hesperidae, Papilionidae, Pieridae, Nymphalidae, Riodinidae, and Lycaenidae (Braby, 2004). And most Riodinidae butterfly founded in South America (Peggie \& Amir, 2006). Indonesia known to have 2.000 species of butterfly that have been identified which $7,5 \%$ of them are Papilionidae butterfly (Noerdjito \& Aswari, 2003). The lack of information of butterfly species database at Kondang Merak beach has increased interest for the researcher to make some researches about butterfly in the area. This research aims to determine butterfly species at Kondang Merak beach thus can provide database of butterfly species in Indonesia.

\section{MATERIALS AND METHODS}

The type of this research is descriptive qualitative. This research was conducted in April 2013. Observations used was standart walk methode (Polard \& Yates, 1993; Swaay et al., 2012). The researcher walked along the research area that has been set $(2,5$ meters left and right from the rute). Butterfly was caught by insect nets and then selected according to the type of species. Butterfly with the same type will be released back to the nature, only a few representative individuals (intact) of each type will be killed and preserved. The research was conducted at $08.00 \mathrm{am}$ until $12.00 \mathrm{am}$ for three time repeated with an interval once a week.

Observation is confined to the outer morphology of butterfly, i.e wingspan (WS), forewing lenght (FWL), color and style of wing that seen from the ventral (underside) and dorsal 
(upperside) to determine the differences in color and wing pattern. Butterflies observed were identified and compared according to the book. The books used to compare are The International Butterfly Book (Smart, 1975), The Complete Field Guide to Butterflies of Australia (Braby, 2004), Practical Guide to the Butterflies of Bogor Botanic Garden (Peggie \& Amir, 2006), and Kupu-kupu Gunung Ciremai dan Sekitarnya (Peggie \& Noerdjito, 2011).

\section{RESULT AND DISCUSSION}

The result shows 40 species belong to the Papilionidae, Nymphalidae, Pieridae, Lycaenidae and Hesperidae Family.

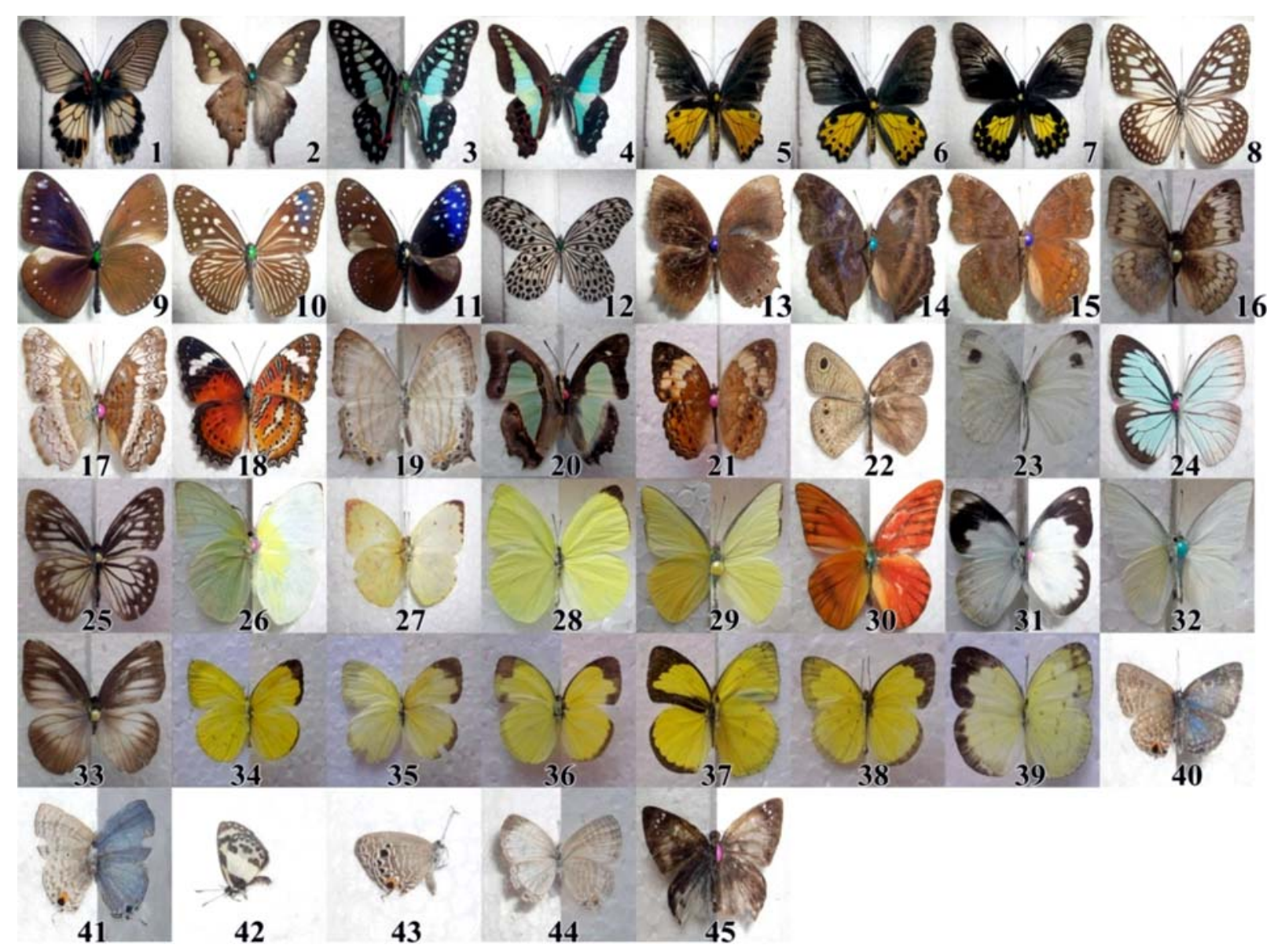

Figure 1. Butterfly at Kondang Merak Beach. 1. Papilio memnon; 2. Grpahium empedovana; 3. Graphium sarpedon; 4. Graphium sarpedon; 5. Troides helena $0^{\star} 6$. Troides helena $\sigma^{x}$; 7. Troides helena + ; 8. Ideopsis juventa; 9. Euploea tulliolus; 10. Euploea mulciber ; ; 11. Euploea mulciber $\sigma^{x} ; 12$. Idea stoli; 13. Elymnias panthera; 14. Junonia iphita; 15. Junonia hedonia; 16. Lebadea martha; 17. Tanaecia palguna; 18. Cethosia penthesilia; 19. Cyrestis themire; 20. Polyura hebe; 21. Cupha erymanthis; 22. Ypthima philomella; 23. Leptosia nina; 24. Pareronia valeria ơ; 25. Pareronia valeria + ;26. Catopsilia pomona $\sigma^{x}$; 27. Catopsilia pomona + ; 28. Gandaca harina; 29. Saletara liberia; 30. Appias nero; 31. Appias indra; 32. Appias albina; 33. Appias lyncida; 34. Eurema blanda; 35. Eurema hecabe; 36. Eurema sari; 37. Eurema tilaha; 38. Eurema andersonii; 39. Eurema sp.; 40. Jamides sp. (1); 41. Catochrysop sp.; 42. Caleta roxus; 43. Jamides sp. (2); 44. Jamides sp. (3); 45. Tagiades japetus. 
Familiy which has the most species is Pieridae with 15 species, while family which has the most number of individuals is Nymphalidae with 39 individuals. In addition, family which has less of species total and individual total is Hesperidae with 1 species and 1 individual.

Table 1. Butterfly at kondang Merak beach based on Family

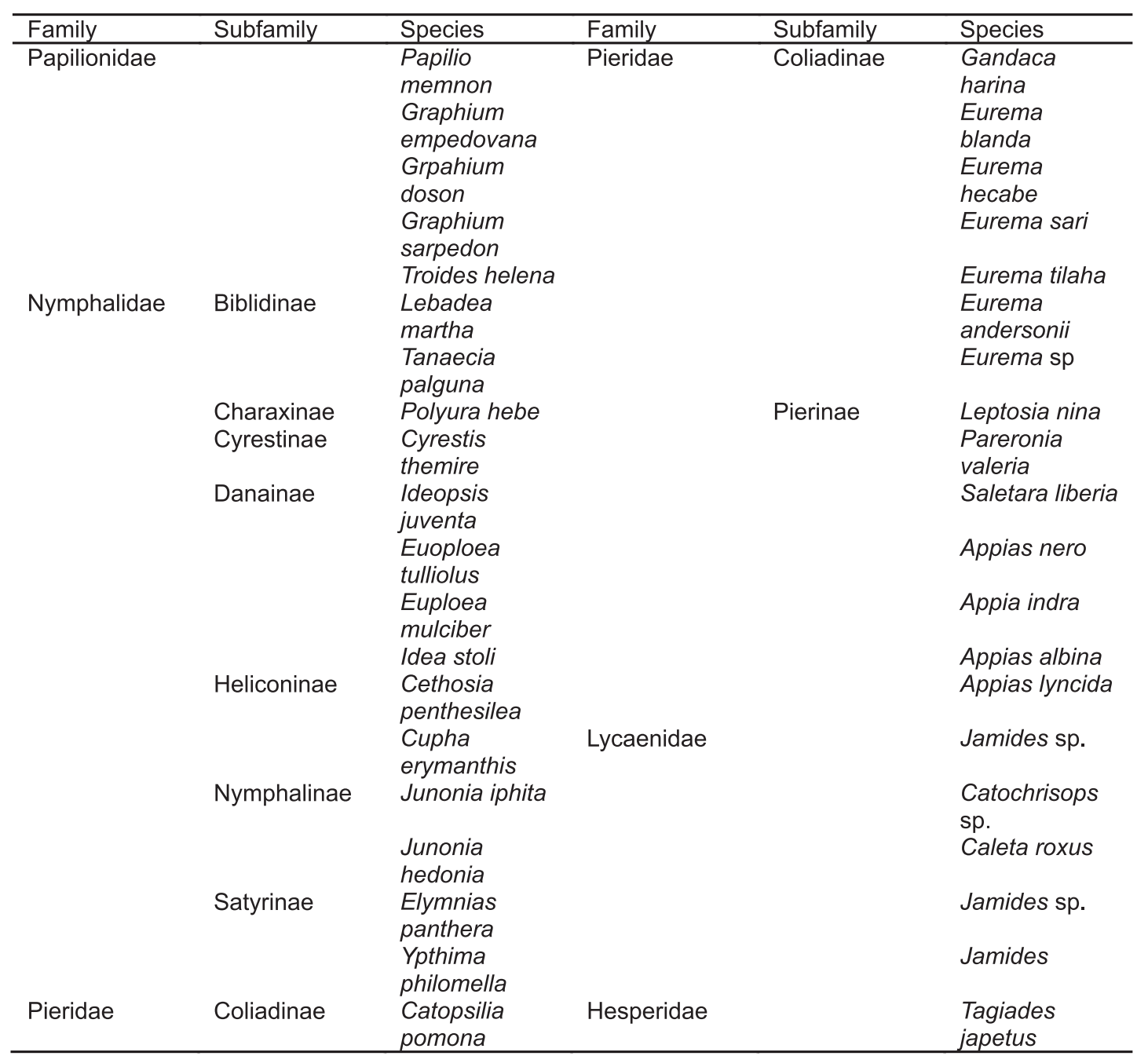

In the observation, most finding was the Nymphalidae Familiy and is similar to the previous researches (Boonvanno et al., 2000; Nimbalkar et al., Ramesh et al., 2010; Sutra, et al., 2012). There are a lot of butterflies from Nymphalidae family found in this study because the number of its species and their life skills. Nymphalidae Familiy consist of abundant individuals and widely spread throughout the world (McCubbin, 1971; Smart, 1975). Besides larvae of Nymphalidae Family is a polifag thus it can spread all over the world (Sutra, et al., 2012).

From the observation, the highest number of species comes from Pieridae Familia because they mostly spreadin tropical regions such as Indonesia. Pieridae with 1,275 species spread across the world, especially in Indo-Australian and in the dissemination of the lowland rain forest to grassland (Heppner, 2008; Orr \& Kitching. 2010). In addition, the larvae of Pieridae butterfly are polifag. Family which has been found in the very small number was Hesperidae Family, because the color and the style of wings were mostly dark brown thus make it difficult to be identified. The familyof Hesperidae prefered to hide under the leaves, thus it is hard to find (Sutra, et al., 2012). 
Ideopsis juventa was commonly found in the area of Kondang Merak Beach because of the existence of many Gymnema plant which can be used as their hosplant. Another host plants for Ideopsis juventa are Pergularia, Piper, and Parsonsia (Peggie \& Amir, 2006; Peggie \& Noerdjito, 2011). From the observations, Troides helena butterfly which has been protected has also been found in the area of Kondang Merak Beach. Troides helena butterfly has been protected by the Minister of Agriculture Decree No.716/Kpts/Um/10/1980 (Noerdjito \& Aswari, 2003), Troides helena has also been included in CITES Appendix II (Coote, 2000).

\section{REFERENCES}

Boonvanno, K., S. Watanasi, and S. Permkam. 2000. Butterfly Diversity at Ton Nga-Chang Wildlife Sanctuary, Songkhla Province, Southern Thailand. Science Asia 26 (2000): 105110

Braby, M.F. 2004. The Complete Field Guide to Butterflies of Australia. Australia: CSIRO Coote, D.L. 2000. CITES Identification Guide - Butterflies. Canada: Minister of Supply and service Canada.

Heppner, J.B. 2008. Butterflies (Lepidoptera: Rhopalocera). 623-626. Dalam: Encyclopedia of Entomology Second Edition (editor Capinera). Usa: SPRINGER

McCubbin, C. 1971. Australian Butterflies. Australia: Thomas Nelson Limited

Nimbalkar, R.K., S.K. Chandekar, and S.P. Khunta. 2011. Butterfly Diversity in Relation to Nectar Food Plants from Bhor Tahsil, Pune District, Maharashtra, India. Journal of Threatened Taxa 3 (3): 1601-1609

Noerdjito, W.A., and P. Aswari. 2003. Metode Survey dan pemantauan Populasi Satwa: Seri Keempat Kupu-kupu Papilionidae. Cibinong: Bidang Zoologi Pusat Penelitian Biologi LIPI.

Orr \& Kitching. 2010. The Butterflies of Australia. Sydney: Jacana Books

Peggie, D., and M. Amir. 2006. Practical Guide to the Butterflies of Bogor Botanic Garden. Cibinong: Bidang Zoologi Pusat Penelitian Biologi LIPI dan Japan: Nagao Natural Environment Foundation Japan.

Peggie, D., and W.A. Noerdjito. 2011. Kupu-kupu Gunung Ciremai dan Sekitarnya. 53-103. Dalam: Fauna Serangga Gunung Ciremai (editor Djunijanti Peggie). LIPI Press.

Polard, E., and T.J. Yates. 1993. Monitoring Butterflies for Ecology and Conservation: The British Butterfly Monitoring Scheme. London: Chapman \& Hall.

Ramesh, T., K.J. Hussain, M. Selvanayagam, K.K. Satpathy, and M.V.R. Prasad. 2010. Pattern of Diversity, Abundance and Habitat Associations of Butterfly Communities in Heterogeneous Landscape of the Department of Atomic Energy (DAE) Campus at Kalpakkam, South India. International Journal of Biodiversity and Conservation 2 (4): 75-85

Smart, P. 1975. The International Butterfly Book. New York: T.Y. Crowell Company.Swaay, C., Brereton, T., Kirkland, P., \& Warren, M. 2012. Manual for Butterfly Monitoring. Netherlands: De Vlinderstichting.

Sutra, N.S.M., Dahelmi, and S. Salmah. 2012. Spesies Kupu-kupu (Rhopalocera) Di Tanjung Balai Karimun Kabupaten Karimun, Kepulauan Riau. Jurnal Biologi Universitas Andalas 1(1): 35-44

Swaay, C., T. Brereton, P. Kirkland, and M. Warren. 2012. Manual for Butterfly Monitoring. Netherlands: De Vlinderstichting. 